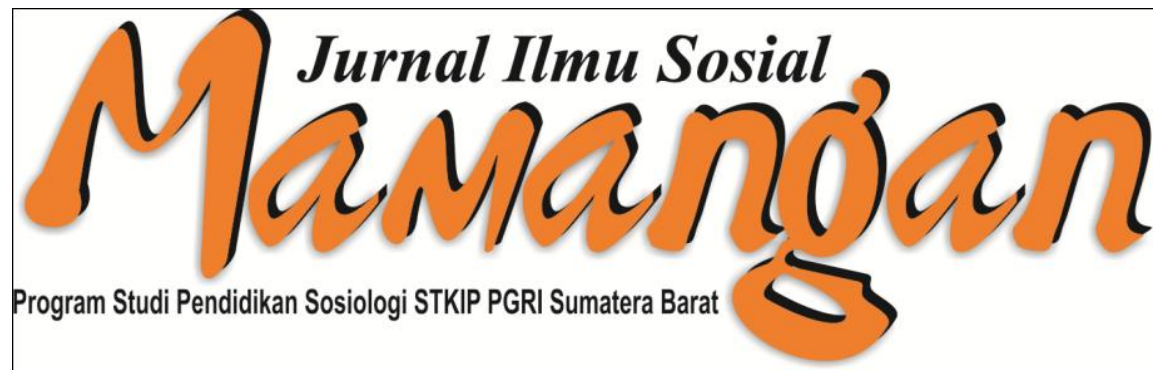

Jurnal Ilmu Sosial Mamangan

Volume 7, Number 2, July-December 2018

Collaboration Of Triple Helix Actors In The Production Of Public Space: The Tematic Park In Bandung

Author : Agus Mauluddin

Source $\quad$ : Jurnal Ilmu Sosial Mamangan, Volume 7, Issue 2, July-Desember 2018

Published by : Laboratorium Pendidikan Sosiologi, STKIP PGRI Sumatera Barat

To Cite the Articel:

Agus Mauluddin, 2018. Collaboration Of Triple Helix Actors In The Production of Public Space: The Tematic Park In Bandung. Jurnal Ilmu Sosial Mamangan, Volume 7, Issue 2, July-December, 2018: 51-61.

Copyright (C) 2018, Jurnal Ilmu Sosial Mamangan ISSN : 2301-8496 (Print), ISSN : 2503-1570 (Online) 


\title{
Collaboration of Triple Helix Actors in The Production of Public Space: The Tematic Park in Bandung
}

\author{
Agus Mauluddin \\ CIC Institute of Research and Social Consultants \\ Email : agusmauluddin@sociologist.com
}

\begin{abstract}
Triple helix actors or three actors are the production actors of public spaces in Bandung thematic park. Triple helix actors consist of government, private and community. Every actor produces their own space in the socio-spatial space of the city. Government as an actor is the executing authority of space production, private actor is outside the government who helped to contribute to the production of space, and community is the production of the socio-spatial space in the city and at the same time as an object of the production of government and private space. Qualitative approaches are used in research by using data collection techniques of observation and in-depth interviews, as well as literature review. These three processes are carried out back and forth as atriangulation of research data. This research shows that the collaboration of actors (triple helix) is required in the production of public space in urban areas, for instance the production of public spaces in Bandung thematic park. However, the most important goal of public space is the space of community as the main actor. Space contestation is inevitable, ultimately based on representational space. Collaboration is a medium to achieve justice in space by responding and placing live space of socio-spatial on economic or political space (pragmatic). Equality in space is created on the protected production of public space from the material interests of private actors and the politics of dominant government actors.
\end{abstract}

Keywords : Public Space, Production of Space, Triple Helix, Bandung

\section{INTRODUCTION}

In the last three decades of the 20th century, development of space theory focused on space production (social). Henri Lefebvre in La production de l-espace (1974) or The Production of Space (Lefebvre, 1991) said that humans have the will to produce space.

Space production in general can be divided into three actors. The production of space consists of production of space for community, government and privat.

In the context of the production of public space in Bandung, capital of the province with the largest population in
Indonesia, space production of those actors is still approximately $12.15 \%$ (data 2015). Some of spaces productions are partial. It is based on regulation No.26 of 2007 that 30\% of the area must be produced green open space.

Based on the data on the availability of public open space in Bandung, there is green open space as an area or a longitudinal and grouped path. This area is opened area where it grows plants naturally and deliberately planted (Regulation No. 26 of 2007). The green open space consists of public and private green open space.

The local government of Bandung has included a draft in the 2011-2031 City Spatial 
Plan of Bandung in order to fulfill the area of open green space in Table:

Table 1:

Existing and Planing of open green space for Bandung based on Bandung City Spatial Plan 2011-2031

\begin{tabular}{|c|c|c|c|c|}
\hline $\begin{array}{l}\text { Type of open } \\
\text { green space }\end{array}$ & $\begin{array}{l}\text { Eksisting } \\
\text { Area } \\
\text { (Ha) }\end{array}$ & $\%$ & $\begin{array}{l}\text { Planning } \\
\text { Area }\end{array}$ & $\%$ \\
\hline River Stream & 18,31 & 0,11 & 18,31 & 0,1 \\
\hline Railroad & 6,42 & 0,004 & 9,63 & 0,06 \\
\hline SUTT & 10,17 & 0,07 & 10,17 & 0,07 \\
\hline Road & 176,91 & 1,06 & 264,34 & 1,58 \\
\hline City park & 218,07 & 1,3 & 2713,9 & 15,92 \\
\hline Cemetary & 148,14 & 0,89 & 292 & 1,74 \\
\hline $\begin{array}{l}\text { Conservation } \\
\text { area }\end{array}$ & 4,12 & 0,02 & 4,12 & 0,02 \\
\hline Others & 436,4 & 2,61 & 92,58 & 0,55 \\
\hline $\begin{array}{l}\text { Public open } \\
\text { green space }\end{array}$ & 1018,54 & 6,1 & 3404,05 & 20,00 \\
\hline Housing & 55,6 & 0,33 & 1090 & 6,36 \\
\hline Security & 114,01 & 0,68 & 60,84 & 0,36 \\
\hline $\begin{array}{l}\text { Education; } \\
\text { trading }\end{array}$ & 722,34 & 4,32 & 549,25 & 3,28 \\
\hline $\begin{array}{l}\text { Private open } \\
\text { green space }\end{array}$ & 891,95 & 5,33 & 1700,09 & 10 \\
\hline $\begin{array}{lr}\text { Open } & \text { Green } \\
\text { Space } & \text { of } \\
\text { Bandung } & \end{array}$ & 1910,49 & 11,43 & 5104,14 & 30,00 \\
\hline
\end{tabular}

Based on the data, minimum standard of the green open space in Bandung is 30\% green open space. There are $20 \%$ public green open space and $10 \%$ private green open space. Existing facts (green open spaces are built) have not shown that issues. Even though, (Joga, N., 2017) states that green cities are important for the subsistence of a healthy, comfortable, productive and sustainable community. That is the obligation of the regional government.

Production of space depends on the contestation of space between actors. Actors in the production of public spaces are mutually contested to get space and practice of their space such as government actors, private actors, and community actors.

The collaboration of actors (triple helix) is required in the production of public space in the city specifically the production of thematic park in Bandung. However, the most important goal of public space is the space of community who are of primary interest of this research. Justice in space is created when the production of public space is protected from the material interests of private actors, and the dominantation of government politics.

\section{RESEARCH METHODS}

This research uses qualitative approach. The qualitative approach of the case study was used in order to discover the collaboration of three actors in the production of thematic park spaces in Bandung. This research discovers the role of government, private and community actors in the production of spaces. The data was collected by in-depth interview techniques and field observations in Bandung thematic park to the informant purposively. In addition, literature reviews are used in this research. These processes are carried out back and forth, and at the same time become a triangulation of research data.

\section{RESULT AND DISCUSSION History of Public Spaces (Parks) in Bandung}

Since the days of the Dutch colony, the local government of Bandung realized the importance of a city park. Then, Bandung was designed to be a park city. Bandung was predicted as developed city, it needed to be anticipated by the construction of parks (Kustianingrum, 2013). So, it is not surprising that Bandung was once Tuinstad or City of Parks (Budiman, 2015). Furthermore, the Bandung Historian, M. Rizky Wiryawan said that Tuinstad referred to the North Bandung area, which at that time was a European residential area (Interview with Informant, 3 May 2018).

In the beginning, the concept of the park in the Dutch colony could be traced since VOC officials built their infrastucture in the 16th century outside the fort in Batavia. The concept of the park was only for private (property) gardens and for leisure. This concept is based on the development of 15th and 17th century European garden planning. In its development, the concept of publicly used city parks emerged only in the 18th century when the industrial revolution took place in 1750 (Budiman, 2015).

(Budiman, 2015) argued that the development of parks in Bandung during the Dutch Colony period was throughout the years 1918-1925. The city parks were built as an important component of the mother's transfer plan of the Dutch from Batavia to 
Bandung. The concept of the park is always included alongside the educational environment, housing, and government offices. This is inseparable from the understanding of Europeans. The development of a good city must be accompanied by the provision of green land and the maintenance of nature. These parks were Molukkenpark, Tjitaroemplein and Oranjeplein. These parks, for example, are adjacent to the facilities of European community facilities. It was Molukkenpark to the Gelora field. Tjitaroemplein was behind the Department of Verkeer \& Waterstaat (Gedung Sate now) which was the official building of the Central Colonial Central Government Agency. Thus, Oranjeplein was built as a complement to the facilities of a luxury housing complex, called Kaptein Hill.

It is similar to the Bandung's Historian M. Rizky Wiryawan. Rizky stated that the actual construction of parks was massively begun since the discourse of moving the central government from Batavia to Bandung. North Bandung area was prepared to be a New City. The concept mimics European cities such as its parks. The New City was also prepared as a shelter for retirees from Europe. The City Government of Bandung issued a slogan "Instead of returning to Europe, it is better to live in Bandung". Furthermore, M. Rizky Wiryawan explained that the purpose of the park was in addition to aesthetics and leisure.

In development of post Netherlands era, during the reign of Ridwan Kamil (20132018), parks in Bandung can be enjoyed by the public for their leisure time. It can be the aesthetics place of the city by being a uniqe place. This place becames crowded. It is discussed by many people. Based on thematic background, every park in Bandung is known as their certain themes. This is the beginning of the emergence of crowded thematic parks in news such as the construction of Jomblo Park (Single Park). The park is unique with packaging of jomblo, which is interpreted by the City Government as a park for residents of Bandung who do not have a partner.

Then, the meaning is disseminated and responded by the citizens. Thus, it is not surprising that various responses rise in various views. Community feels the policies of the Bandung government are a positive thing due to the creation of thematic parks for their citizens, for example the creation of Jomblo thematic park. However, other different responses emerged such as the creation of thematic parks by the government only beneficial for developers or private actors. Private actors can advertise their products with being unrecognized by community through the branding of thematic park. It is a result of government policies that hand over funding to private parties or private sector. Thus, it becomes an important analysis related from previous studies.

\section{Related Study of Space Production Actors}

Public space is produced differently by each actor. The public space is contested as commodity. In the production of public spaces, there are various actors such as government, private sector, and society.

(Mahendra, 2013) emphasizes that the contestation won by the community. Community empowerment is created. In his research, community manages parking lots. Whereas, other researchs are different (for example, Hackenbroch, 2013; (Damajani, 2007); (Handoyo, 2015); (Cahyono, 2012); (Iswari, S. A., 2014)), observing more at the obvious space contestation. There are contested of the production of community space in uncertainty. (Afrizal, 2013) further explained that space contestation in modern society is dominated by the need for money, which involves various actors, such as the state, business, and civil society. (Aminah, 2015) discovered that it was not only due to contestation in space by government, community, and investor, but space conflicts also occured.

(Hanckenbroch, 2013) is more focused on the symptoms of public space used by informal institutions of urban poor people to sustain their daily livelihoods. Negotiations between actors and power dominated this case. Likewise, the study of (Damajani, 2007) explains that the negotiation space is needed by the community. In his research, Damajani saw more informal space than formal space. Fascinatingly, Damajani's research discovered that the informal spaces in negotiation room could be formal with various agreements. In this case, there is sharing space, sharing time and so on. Street vendors are transformed from irregular and organized (informal) into arranged and organized. It is well placed. It turns out to be 
formal (in the formal space). It may only apply on certain days such as Sundays with certain times from $6 \mathrm{am}$ to $12 \mathrm{pm}$. It is different in (Ramadhani, B., \& Pontoh, 2015) research that focus on space contestation differently. In this research, the government has the most roles in the production of space. Then, it needs to focus on the creative community. The private sector needs to play a role in the creation of themes, especially the image of the company.

In addition to the contestation in the production of urban public spaces, there is the importance of collaboration in producing urban public spaces. Synergy is important part by various actors (Pamungkas, D.R., Sarwono, 2014);(Ramadhani, B., \& Pontoh, 2015). It is slightly different from the other studies that looked at production and space contestation, such as (Neuman, A. \& Lund, 2016). This research considered from the historical context, while Leitner and Sheppard (2017) looked firmly at the contestation of actors.

Leitner and Sheppard (2017) focus on all cities in the global south. Leitner and Sheppard are initiating land collection from informal settlements to provide large-scale infrastructure and commercial real estate projects. Jakarta as a case study showed a contestation in the resettlement of the villages of Pulo and Bukit Duri on Ciliwung River. There was contestation among residents, the provincial government, the developers or community elites, and middle class. (Neuman, A. \& Lund, 2016) focus on the history of land control in Indonesia as one of the colonial conquests, and the takeover of traditional ownership rights. However, behind this great transformation, the backflow also happens. State land encroachment and gradual privatization by ordinary people sometimes undermines government property. Through a series of small and sometimes harmless actions, ordinary people managed to overturn the previous ownership regime (the government, in the case of Neuman and Lund's research, was PT Kereta Api Indonesia or railroad companies). His study also discovered settlement managed to adjust, formalize and effectively privatize land owned by stateowned railroad companies in Bandung. This area is used over 30 years. Thus, it affirmed the contestation of community actors with the government that ended with the support of community actors.

(Putra, E. A. H., \& Khadiyanto, 2014) stated that private admission to the public space led to social inequality and social exclusion. The spaces based on socioeconomic status in public open spaces. In addition, community rights (especially middle-lower social classes) are limited and they are excluded from comfort zone in public space compared to certain social classes for example middle-upper class. This happened due to the privatization of public open space. Private actors open cafes and karaoke. The case was found by their research in the public open space of Tabanas Gombel park Semarang. Middle-upper class visitors will choose to visit a restaurant or cafe because it provides a better location, complete supporting facilities and can eat food while enjoying the view. Meanwhile, visitors with low budget and willingness to pay will choose to be in the Tabanas park, even though there are no supporting facilities and flexibility in enjoying disturbed views by restaurants, cafes and higher karaoke buildings. This research aims to trace the possibility of privatization in the production of public spaces in parks that have a negative impact on the production of community spaces.

There are different perspectives in some researchs; one of the research is (Erensü, S., \& Karaman, 2017) about the existence of life space in the case of Gezi in Turkey. The article shows the impact of political unrest deepens and develops not only through maintaining space but also creating new material and conceptual. (Erensü, S., \& Karaman, 2017) refer to Lefebvre and Harvey. The article mentioned that under the leadership of the AKP party in authoritarianistic Turkey, intervention in space was so obvious. It is proven by the redevelopment of the commercialization of public parks located in most of the center of Turkey, without compromise. Yasam Alani (life space) is as a shelter that has autonomy from the value circuits of capital accumulation. Life space is connoted with a safe space where people can breathe, enjoy and express themselves. Social movement activists mobilize through social media to maintain life space by Gezi Demonstrations. It is supported by the argument of (Dikeç, M., \& 
Swyngedouw, 2017). The research shown that urban uprising was important in the politics of the city. It is not a matter of violence, but it searchs political of equality and freedom.

(Mitchell, 2017) mentions that the finale of public space in American is privatization. (Mitchell, 2017) shows that the tendency towards the end of public space in capitalism is closely related to capitalism's need to produce abstract space. It is a case study in the East Bay of California (Berkeley and Oakland), then critically interrogating the end of public space thesis is privatization. In addition, (Mitchell, 2017) explains David Harvey's manuscript argument about the rise of the entrepreneurial city and Ed Soja's argument about a postmodern city which in many ways matches Davis's argument. In general, it focuses on public space in critical analysis. Mitchell quoted Davis about the homeless crisis as a crisis of the public sphere. It defended the use of displaced people, whom they considered necessary to order in the city. It supported the regulation of new quality of life to regulate the use of homeless public spaces and perhaps to eliminate them altogether. However, the homeless population continues to grow and find shelter in parks, sidewalks, riverside campsites, or elsewhere. There are no other shelters available, they are not safe or they are closed during the day. Homeless people impose questions about public space such as the relation to the dynamics of property changes in the city, and so on. Jeremey Waldron said (in (Mitchell, 2017), homeless people can only live as humans being until they have access public space. Homeless people need public space. In his writing, he questioned whether public space is public property, built through practice (which is customary and debating) or state and developer property. He also questioned whether public space is a space to live or space for visiting. Thus, it confirms privatization as contestation on the production of space for each actor.

Thus, it is important to discuss the relationship of the involvement of the three actors (triple helix) in the production of public spaces in the thematic park of Bandung. The study also positioned the space negotiation process and the importance of the collaboration of the three actors in the previous study of scientific research. It investigates the involvement of government actors, private actors, and community actors. Is there correlation between these actors? Thus, development in a city can be built fairly especially related to parks in urban areas. This research wants to discover the most important actor to be positioned than other actors.

Thus, it is important to discuss the relationship of the involvement of the three actors (triple helix) in the production of public spaces in the thematic park of Bandung. The study also positioned the space negotiation process and the importance of the collaboration of the three actors in the previous study of scientific research. It investigates the involvement of government actors, private actors, and community actors. Is there correlation between these actors? Thus, development in a city can be built fairly especially related to parks in urban areas. This research wants to discover the most important actor to be positioned than other actors. It is necessary to explain the roles of actors in the production of space before being discussed in depth about the interrelationships between the three actors in space production. Thus, society can understand properly and government can consider the partnership portion of private.

\section{Triple Helix Actor in Production Public Spaces of Thematic Park in Bandung}

\section{Government Actor}

The city government has power over public space in a city. The local government is one of the actors who have a representation of space with the elite of the community such as urban planners, urban leaders, architects, and others. It determines the production of public space in urban areas, in this case the city of Bandung.

Ridwan Kamil, Bandung Mayor (20132018), has an idea in building cities by public private partnership system. The involvement of the private sector has become a major of urban development because of the limitations of the Regional Budget. Ridwan Kamil is not only using funds from APBD (government fund) in building cities (Kamil, 2017).

Yayat Supriatna, urban planning observers, said that the collaboration of actors was indeed needed especially to help government budgeting. Nevertheless, the 
presence of the government towards the community must exist for example by providing subsidies. Related thematic gardens public spaces in the city, the triple helix collaboration is important. The goal is to equalize the vision and interests of the government. Sometimes, the government considers the vision of their interests as the target, the project is built. The community considers the purpose of building a public space may not be the needs of the community itself. Therefore, the dialogue is important to define the vision. It stucks on the project approach. The problem is the arguments of "I have money, I have a program" (interviews and discussions with informants, 11 April 2017).

The involvement of representation of space in the production of thematic park in public spaces of Bandung is evident. The government actor built a park with private actors based on the conceived space. (Ramadhani, B., \& Pontoh, 2015) mentions the branding label of a cellular telecommunications provider in Taman Centrum and branding a camera shop and photography in Cempaka Park. In Jomblo Park, space is interpreted differently by the government actors (contestation) and community actors.

Space production can also be interpreted as spatial practice. According to (Lefebvre, 1991), this space practice is dominated by representations of space and makes it a true space. Space should be owned by the community as representational space.

In fact, the representational space in the practice of the thematic park of Jomblo must disappear into the representation of space because the power of representation of dominated space (Lefebvre, in(Ritzer, 2010).

(Somantri, 2007) stated the state (in this case the Bandung local government) as an actor has control thru his power. City development is dominated by the state (government actors) (Wu, 2016);(Wu, Q., Edensor, T., \& Cheng, 2018).

Practically, production of government space in Jomblo thematic garden space is not only in spatial space. However, the production of space exists in the realm of the meaning of actors (local government of Bandung).

Each the parks in Bandung are themed, for example Singles or Jomblo Parks. "The theme" Jomblo becomes the term produced by the local government of Bandung. The meaning is distributed to the wider community especially residents of Bandung through social media (such as Instagram, Twitter, Facebook, etc.) by Ridwan Kamil. Moreover, the Mayor likes to use social media.

As mentioned by Professor of Urban Anthropology in The City University of New York (CUNY) Setha Low1 (Lefebvrian) that public space is not only interpreted as public space (for example, roads, parks, shopping centers, government), but also public spheres (abstract / non-physical spaces such as the internet and social media (Low dan Smith, 2006).

Space production in the practice of space by the government in the Jomblo park is the production of spatial space (Singles thematic garden concretely) and space production in the realm of actors meaning making (in this case the local government of Bandung or Mayor of Bandung Ridwan Kamil). Space production is referred to as the representation of space with other actors such as private actors who produce space.

\section{Private Actor}

Private actors in space production often become the government actors. The government always argues that private involvement with the Public Private Partnership system as the leader of urban development because of the limitations of the Regional Budget (Kamil, 2017).

Based on the JNE website (www.jne.co.id) in the publication column, it is stated that the private sector is helping the local government to improve the community's happiness index and realizing the clean and green city of Bandung. Revitalization aid in the Park of Bandung such as Taman Jomblo is not only limited to the physical but also the theme. M. Feriadi as President Director of JNE said, "Connecting Happiness is a spirit that must be carried out, not only in providing excellent service to customers, but also in various programs that

\footnotetext{
${ }^{1}$ Researcher has the opportunities to correspond with Prof. Setha Low by email. Setha Low, Lefebvrian, is a friend of David Harvey, Deborah, and Dolores Hayden. Prof. Setha Low confirms the substance of the article that the researcher review.
} 
provide benefits throughout Indonesia." (JNE, 2017).

Thus, it is the production of space for community actors in the practice of space in Jomblo Bandung thematic park (which is opposed to the production of space for government actors and privat actors).

\section{Community Actor}

Lived space is the space to live. There are symbols such as canteen in campus. The canteen room feels unique because it is lived space. Society give symbols, memory and so on. The representational spaces is different with the conceived space (conceptualized by architecture, urban planners, etc.), because representation of space is related to modes of economic production. It is contrast to the memory, symbolic dimensions of representational space for example the eviction of the village for the sake of housing, the developer already has permission from the local government (Lefebvre, 1991).

In the context of Jomblo Park, it becomes representational space (lived space). The space is the practice of community space. It embodies symbols, memory, and so on. Jomblo Park is not only limited to spatial space, but the production of community space in daily space practices embedded in collective memory. A merchant has long been selling around Jomblo thematic parks (even before the establishment of thematic parks, space under the Pasupati flyover). Merchant has a unique impression because the production of space in the practice of space becomes representational space (perceived space).

Based on the interview, a mother is eager to sell even though she is old enough. She fulfills the needs for herself and her children. Since 1980s, she has to move around Bandung because her place is in informal place. She started to sell below the flyover about 4 years ago by asking permission from the local government (Interview with $\mathrm{M}$, merchant, on January 23rd, 2017).

Based on the informan's information, merchant has their own space representational. It is already embedded memory and emotion in the practice. It must be willing forcibly evicted by government as the representation of space (conceived space). It is conceptualized by government actors in which can not be separated from the role of private actors who influence the production of government actors. The production meaning of space for informan $M$ about thematic park of Jomblo Park is indeed the same as before. $M$ takes an informal space. However, informant $\mathrm{M}$ obtained his space by negotiating with the local authority to get space and make room production (selling). In many cases, space negotiations (on the government) is happened through local people such as thugs (positive connotations (Paredes, 2002).

Space negotiation arises because of the existence of space contestation in the production space of each actor. Government, private, and community actors compete for space. Then, space negotiations appear between the triple helix. Referring to Lefebvre's approach to Marx, Lefebvre took his inspirational method to develop deep criticism of urban processes under capitalism (Perucich, 2018). Communities with various social strata (including the poor and middle class) must get space, from capitalism.

(Lefebvre, 1991) stated humans as social beings capable of producing their lives or space with their consciousness humans form their own world (conception of social space). Space production is inseparable from the relationship between space and its activities (space practice).

The practice of space needs to be ensured the sustainability of the community's social cohesion (Lefebvre, 1991). Every citizen has the right to the city and has the opportunity and equality in the production of space to achieve collective happiness and a better quality of life ((Lefebvre, 1991);(Pamungkas, 2016).

The practice of space in the Jomblo Park by residents of Bandung in park management (space production), was involved in the local government. It is especially to the head of RW (Rukun Warga), who is mandated to manage the park, by involving residents in his neighborhood. As revealed by the head of RW 11 at the research location:

My responsibility is not only as an administrator of RW 11, but I also manage of the park. Thus, I empower the local community to care for the park, both in terms of hygiene care, or in the maintenance of security. I involve the main community, not from outside. (Interview with $S$, the head of RW 11, September 23rd, 2017). 
The informant mentioned that he had the authority to manage the park and recruit residents in his neighborhood. The informant further explained that the residents who had been appointed by S, the head of RW 11, were given the capacity as workers who were employed to care for thematic parks. In addition to managing the park, residents produce space by selling in the area around the park. As stated by informant $\mathrm{S}$, "there is a trade around the park that is also a local citizen."

The community in RW 11 has a conception of thematic park public spaces based on their awareness of space production. Residents produce park spaces to sell. Other residents work to maintain cleanliness and the security of the park.

Production of other community actor spaces expressed by AN, who served as vehicle parking guards.

AN informant, said:

The Parking lots in this thematic park is just below the Pasupati flyover. It is managed by local residents. Parking lots for motorized vehicles are managed independently by the community. (Interview with AN, parking attendant, January 23rd, 2017).

Parking lots for car turns out to provide day care (24 hours / 1 night) by IDR 25,000,-. It is more expensive than the usual parking fee of IDR 5000, -. The guard is directly in front of the guard post (Observation January 23rd 2017).

Production space of community as representational space gives a unique impression on the space they produce. Interview with traders in thematic parks, on January 25th, 2017, a meatball trader who owns his own cart and sells around the Jomblo Thematic Park, said that he was not a native of Bandung, he was a migrant from Solo. He needs to pay for the place because he is newcomer. The informant said, the cart is his own. He needs to pay the rented stalls or places to the head of RW, Rp. 300,000, - per month that includes electricity costs. In addition, he said that in addition, he worked in the cleaning department, from morning to noon, then afterwards selling meatballs.

Based on the data, there is a problem between preserving absolute space such as green trees in Bandung, representational space (production of community space) by building spaces for the investors. Thus, it depends on how the space contestation occurs between the government, the private sector and the community.

It has been cautioned by Lefebvre (cf. (Ritzer, 2010) \& (Gottdiener, M., \& Hutchison, 2011)in relation to space production, he discovered the existence of a struggle for absolute space such as green trees. This absolute space is intended for the ecosystem of a city, but still there are contestation between space for society and political economy. In abstract space, power will dominate space according to their interests. Then, this abstract space appears as an oppressive space, because it is controlled by domination. (Lefebvre, 1991) firmly defined that "abstract space is a tool of power". Thus, powerfull actors are ultimately destroyed abstract space and absolute space (nature, green spaces, trees) for the sake of political economy as the winner of space contestation.

In the end, the involvement of the actor who contested and won the space must be based on the justice of the space by the community. Thus, it needs to define the vision of the triple helix actors for the sake of the production of community space.

\section{Collaboration of Triple Helix Actor}

Space production in the Jomblo Park engages the colaboration of government, private, and community. It is based on the informant S of RW 11:

If there is no coordination and synergy between the government and the community, it will not be long periode for the park. (Interview with S, Head of RW 11, September 23rd, 2017).

It needs to be emphasized the collaboration with the local Government in relation to representational space. The involvement of community around the park is a priority of development and park management. The involvement of Government actors is their capacity as coordinator of the implementation of the park.

Furthermore, the procedure of coordination was revealed by informant $S$, the head of RW 11:

The procedure of coordination is on event to get licensing to DPKP3. Then, it is recommended to the RW. Then, I recruit the community to convey the appeal instructed 
from DPKP3 (Interview with S, Head of RW 11, September 23rd 2017).

One of the procedures of coordination is licensing to formal legal administration such as correspondence. However, related to management, the leader is involving local community because it can impact socioeconomic of community. If there is an art performance, the committee can involve citizens. If the event is from outside (such as from the Campus), community can be involved in security, parking attendants, and park cleanliness.

The involvement of community also received an appreciation of salaries, as stated by informant $S$, the head of RW 11:

Yes. There is salary for volunteers because everyone will not want to do it without getting money. The income is from DPKP3 as the management of the park. There is CSR from PT Multi Strada as a guard to protect the park in the night. If no one keeps the park, it can be misused continuously. So, the assets can also be lost. The facility will be broken. (Interview with S, the head of RW 11, September 23rd, 2017)

Appreciation to community involvement in salary has an impact on the socio-economic community. Practically, the procedure in night shift by community creates engagement of community to Jomblo Park. However, vandalism still remains beyond community. Thus, the park is not always well maintained by the security of citizens.

This research also intestigated several thematic parks outside the Jomblo Park. It was for comparison in the context beyond the locus of research such as Pet Park. This park is a space for pet lovers. This park is very indulgent for the middle-up class because they have leisure time to play with pets. Upper middle class have more leisure ownership. On the other hand, the lower middle class may not have it because more time is used to search for daily economic needs (Observation at Pet Park, January 22nd, 2017).

Pet Park provides various facilities such as an interaction space between pet owners by providing seat facilities. In addition, various facilities for pets are available. This park is provided place to play and practice the agility of the pet. On the other side of this Pet Park, there are street vendors who decorate the edges of the park on the streets.
In addition, parking lots are provided at the Pet Park but its parking lot must share space with passing car.

The observations were also carried out in the Lansia Park (Elderly Park). This park is not used by the elderly or someone who is in old age. Various circles adorn this park such as millennial generation, family, and young couple. If you have ever been to the Lansia Park, you will be able to find street vendors and vendors passing by in the park offering merchandise. There are facilities such as seats for interaction spaces and places to eat from various foods offered by street vendors. Various kinds of space production are created in the Lansia Park space.

The production of space for tripel helix actors will run fairly if there is transparency in negotiating money between actors. If there is the absence of transparency such as socialization to community actors related to development, it can lead to mutual accusations in the community about consolidation between government actors and private actors (Irwandi dan Chotim, 2017).

Researcher tried to do the comparison to other case studies. In educational institutions such as Islamic boarding schools, they cooperate with private actors such as the business area or even the Ministries of Industry and Agriculture to sustain sustainability. That is important (Hasbullah and Rahman, 2018). Even so, the same thing also happed in religious institutions. It is importance to keep distance from forced power of government actor. However, it must be autonomous in its community. In fact, this institution must be a counterweight and criticism of government and private actors (Hefner, in Mauluddin, 2018).

Thus, community actors can balance and even critics of the government and private actors. Community can not give power to these actors to force the community in the context of the collaboration of actors triple helix.

\section{CONCLUSION}

Community actors are the main goal in urban space production. The collaboration of triple helix actors (government, private, and community) is one of the media to realize space justice. Equality in space is the condition of the protected production of 
public space from the material interests of private actors and the politics of dominant government actors.

Transparent collaboration and negotiation spaces are key point in creating space justice. The triple helix actor unites the vision in developing their city.

\section{REFERENCES}

Afrizal. (2013). Tinjauan Sosiologis Terhadap Keadilan Ekologis. Mamangan, 1 no 1.

Aminah, S. (2015). Konflik dan Kontestasi Penataan Ruang Kota Surabaya. MASYARAKAT. MASYARAKAT: Jurnal Sosiologi, 2 no 1, 59-79.

Budiman, H. G. (2015). Perkembangan Taman Kota di Bandung Masa Hindia Belanda (1918-1942). Patanjala, 7 No 2, 185200.

Cahyono, U. J. (2012). Pengelolaan Ruang Publik di Sekitar Persimpangan Jalan. Jurnal RUAS, 10 No. 2.

Damajani, R. D. (2007). Informalitas Dalam Formalitas Pada Ruang Terbuka Publik (Studi Kasus Lapangan Gasibu, Bandung). Jurnal Dimensi Teknik Arsitektur, 35 No.2, 164-171.

Dikeç, M., \& Swyngedouw, E. (2017). Theorizing the Politicizing City. International Journal of Urban and Regional Research, 41 no 1, 1-18.

Erensü, S., \& Karaman, O. (2017). The Work of a Few Trees: Gezi, Politics and Space. International Journal of Urban and Regional Research, 41, 19-36.

Gottdiener, M., \& Hutchison, R. (2011). The New Urban Sociology. USA: Westview Press.

Hanckenbroch, K. (2013). Negotiating Public space for livelihoods: About Risks, Uncertainty and power in the urban poor's everyday life. Erdkunde.

Handoyo, E. (2015). Makna Ruang Publik bagi Pedagang Kaki Lima: Studi Tentang Resistensi terhadap Penggusuran. Seminar Nasional Unisbank.

Irwandi dan Chotim, E. R. (2017). Analisis Konflik antara Masyarakat, Pemerintah, dan Swasta. JISPO, 7 No 2.

Iswari, S. A., \& N. (2014). Efektivitas Taman Sriwedari sebagai Ruang Publik di Kota Surakarta. Jurnal Teknik PWK, 3 No 4.

Joga, N., et. al. (2017). Kota Cerdas Berkelanjutan. Jakarta: Gramedia
Pustaka Utama.

Kamil, A. D. G. W. R. (2017). Interview. CNN.

Kustianingrum, et al. (2013). Fungsi dan Aktivitas Taman Ganesa sebagai Ruang Publik di Kota Bandung. . Jurnal Reka Karsa, Jurusan Arsitektur Itenas, 1 No 2.

Lefebvre, H. (1991). The Production of Space. Massachusetts: Blackwell Publishers Ltd.

Mahendra, D. A. S. (2013). Studi Pemanfaatan Ruang Publik untuk Lahan Parkir di Kota Blitar. Jurnal Bumi Indonesia, 2 No 3.

Mitchell, D. (2017). People's Park Again: On the End and Ends of Public Space. Environment and Planning, 49 No 3. Neuman, A. \& Lund, C. (2016). On Track. Spontaneous Privatization of Public Urban Land in Bandung, Indonesia. South East Asia Research, 24 No 1.

Pamungkas, D.R., Sarwono, \& H. A. (2014). Perencanaan Pembangunan Ruang Publik untuk kebutuhan anak (Studi di Kecamatan Pare Kabupaten Kediri). Jurnal Administrasi Publik (JAP), 2 No 4, 722-728.

Pamungkas, A. S. (2016). Produksi Ruang dan Revolusi Kaum Urban Menurut Henri Lefebvre. Lkip Edisi 31. Retrieved from https://indoprogress.com/2016/01/pr oduksi-ruang-dan-revolusi-kaumurban-menurut-henri-lefebvre/

Paredes, O. T. (2002). Capital, Coercion, and Crime: Bossism in the Philippines, John T. Sidel. Journals.openedition.otg/moussons/27 74, 137-139.

Perucich, J. F. V. (2018). Book review: Marxist Thought and the City. Urban Studies. university of mingesota pres.

Putra, E. A. H., \& Khadiyanto, P. (2014). (2014). Pengaruh Privatisasi Ruang Terbuka Publik Taman Tabanas Gombel Semarang terhadap Tingkat Kenyamanan Pengunjung. Jurnal Teknik PWK, 3 No 3.

Ramadhani, B., \& Pontoh, N. K. (2015). Identifikasi Keterlibatan Pemangku Kepentingan pada Pembangunan Taman Tematik di Kota Bandung. Jurnal Perencanan Wilayah Dan Kota 1 SAPPK, 4 No 3.

Ritzer, G. (2010). Sociological Theory 8th edition. New York: McGraw-Hill.

Somantri, G. R. (2007). Contesting Urban 
Land: A Strategic Groups' Analysis of Urban Social Disparities in Jakarta, dalam Migration within Cities. Jakarta: Lembaga Penerbit Fakultas Ekonomi Universitas Indonesia.

Wu, Q., Edensor, T., \& Cheng, J. (2018). Beyond Space: Spatial (Re)Production and Middle-Class Remaking Driven by Jiaoyufication in Nanjing City, China. International Journal of Urban and Regional Research, 42 no 1, 1-19.

Wu, F. (2016). State Dominance in Urban Redevelopment: Beyond Gentrification in Urban China. Journals

Permission.nov, 52 No.2, 631-658. 